\title{
CHARACTERISTICS OF ATOPIC DERMATITIS IN PUSKESMAS (PUBLIC HEALTH CENTER) MASARAN 1 SRAGEN REGENCY
}

\author{
Muhammad Ilham Arifin Munthaha ${ }^{1 *}$, Retno Indar Widayati ${ }^{2}$, Liza Afriliana ${ }^{2}$, Aryu Candra $\mathrm{K}^{3}$ \\ ${ }^{1}$ Undergraduate Program, Faculty of Medicine, Diponegoro University, Semarang, Indonesia \\ ${ }^{2}$ Department of Dermatology and Venereology, Faculty of Medicine, Diponegoro University, Semarang, Indonesia \\ ${ }^{3}$ Department of Nutrition Science, Faculty of Medicine, Diponegoro University, Semarang, Indonesia \\ * Corresponding author, E-mail: arifinmunthaha7@ gmail.com
}

\begin{abstract}
Background: Atopic dermatitis is a chronic and residive inflammatory skin disease with mild to severe itching and occurs mostly in infant and children. The cause is not certainty known and multifactorial. Objective: This study aims to know the characteristics of atopic dermatitis in Puskesmas Masaran 1, Sragen Regency. Method: This study is a descriptive study with a retrospective cross-sectional design. Secondary data obtained from medical records atopic dermatitis patients at Puskesmas Masaran 1 in the period 1 January-31 December 2019 with a sample 248 people then analyze using a computer program. Result: The most atopic dermatitis sufferers were the adult age group (151 people), female gender (139 people), not working (96 people), atopic history disease found in 112 patients, site of the most lesions was lower extremities (71 patients), and the choice therapy is polytherapy with three types of drugs in 103 patients. Types of drugs are corticosteroids (224 patients), antihistamines (212 patients), and vitamins/minerals (200 patients). Conclusion: Characteristics of atopic dermatitis in Puskesmas Masaran 1 are the most age group is adults, gender is female, types of work is not working, atopic history is atopic dermatitis, and therapeutic options are corticosteroids, antihistamines, and vitamins/minerals.
\end{abstract}

Keywords: Atopic dermatitis, age, gender, occupation, atopic history, location of lessions, therapeutic options.

\section{INTRODUCTION}

Atopic dermatitis is an inflammatory skin disease that is chronic and residing, characterized by mild to severe itching, recurring, occurring in individuals with a history of atopic in themselves or their families, and most appearing in infancy and childhood. ${ }^{1-3}$

The etiology and pathogenesis of atopic dermatitis are not specific and are multifactorial. Atopic dermatitis triggers include intrinsic factors such as genetics, patient skin characteristics, immunological disorders, stress, and extrinsic factors such as irritants, allergens, food, microorganisms, and weather. ${ }^{46}$

Several theories are explaining their pathogenesis. One of them is skin barrier permeability dysfunction. In atopic dermatitis, there is a dysfunction of the epidermal barrier's permeability due to loss of function/mutation of the filaggrin gene (FLG). FLG gene encodes pro filaggrin protein as a precursor to the structure of FLG protein in complex epidermal differentiation. FLG protein is a crucial protein in forming the keratin layer and plays a role in the stratum corneum's hydration. FLG is expressed in keratohyalin granules during terminal epidermal differentiation. After keratinocytes become solid, FLG protein releases a natural moisturizing factor (NMF). The loss of the FLG gene function causes the skin to become dry. ${ }^{4,7,8}$

Atopic dermatitis is also associated with elevated serum immunoglobulin E (IgE) levels and a family history of atopic, such as rhinoconjunctivitis, bronchial asthma, atopic dermatitis, and food anaphylaxis. Skin disorders may include itchy papules and then experience excoriation and lichenification, distribution often in skin folds (flexural). ${ }^{2,9}$

Atopic dermatitis prognosis is based on prognostic factors, namely early onset in infants ( $<6$ months), severe manifestations of atopic dermatitis, socioeconomic burden, single children, high IgE concentrations, and presence of respiratory atopic disease. The diagnosis of atopic dermatitis cannot be confirmed only by clinical features but must be by anamnesis. There are several diagnostic criteria for atopic dermatitis but the criteria most often used are the

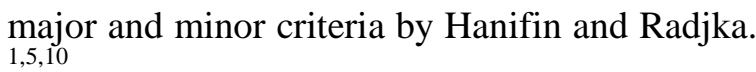


Muhammad Ilham Arifin Muntaha, Retno Indar Widayati,

Management of atopic dermatitis depends on the stage of the disease, consisting of essential adjuvant therapy (skin protection), identification, and elimination of trigger factors (irritants, allergens, infectious agents, and emotional stress), and if necessary, antiinflammatory is given. Maintaining skin moisture can be done by bathing or wet dressing (wet dressing). This management emphasizes long-term therapy (long-term-control) so that therapy is to treat symptoms and be accompanied by patient education about proper skincare and avoiding its causes. Also, each patient requires individual management to try various treatment types until they reach the ideal combination of treatments. ${ }^{5,11}$

Puskesmas (Public health center) Masaran 1 is one of 25 Puskesmas in Sragen Regency. This Puskesmas already has accreditation A. According to monthly patient data reports (LB1 Puskesmas), dermatitis occupies the most common skin diseases in Puskesmas Masaran 1. The most common diagnosis of various dermatitis is atopic dermatitis, followed by contact dermatitis. However, there is no identification of atopic dermatitis characteristics in Puskesmas Masaran 1, Sragen Regency. The independent variables chosen were age, gender, profession, history, location, and treatment. These variables are factors related to the course of atopic dermatitis. This study aims to determine atopic dermatitis characteristics in Puskesmas Masaran 1, Sragen Regency.

\section{METHODS}

This research was conducted at Puskesmas Masaran 1, Sragen Regency in August 2020. The research method was descriptive with a retrospective cross-sectional design. The study population was atopic dermatitis patients at Puskesmas Masaran 1, Sragen Regency. The samples of this research were atopic dermatitis patients at Puskesmas Masaran 1, Sragen Regency, who met the inclusion and exclusion criteria. The inclusion criteria were medical records of atopic dermatitis patients from January 1, 2019, to December 31, 2019, which fulfilled the variables studied. The exclusion criteria were missing medical records or incomplete written data. The minimum sample size is 196 people, with a total sample of 248 people studied. The study's independent variables were age, gender, profession, history of atopic disease, location of lesions, and drug of choice. The tools and materials used were stationery, and the type of research data was secondary data. The processed data will be processed with computer software and then presented in tables and percentages.

\section{RESULTS}

\section{a. Distribution of atopic dermatitis by age.}

Table 1. Distribution of atopic dermatitis by age

\begin{tabular}{ccc}
\hline Age group (years) & $\begin{array}{c}\text { Number of } \\
\text { Patient }(\mathbf{N})\end{array}$ & Percentage \\
\hline Infant (0-1 years) & 10 & $4 \%$ \\
Child (2-9 years) & 43 & $17,4 \%$ \\
Adolescent (10-19 & 44 & $17,7 \%$ \\
years) & 151 & $60,9 \%$ \\
Adult ( $\geq 20$ tahun) & 248 & $100 \%$ \\
Total & &
\end{tabular}

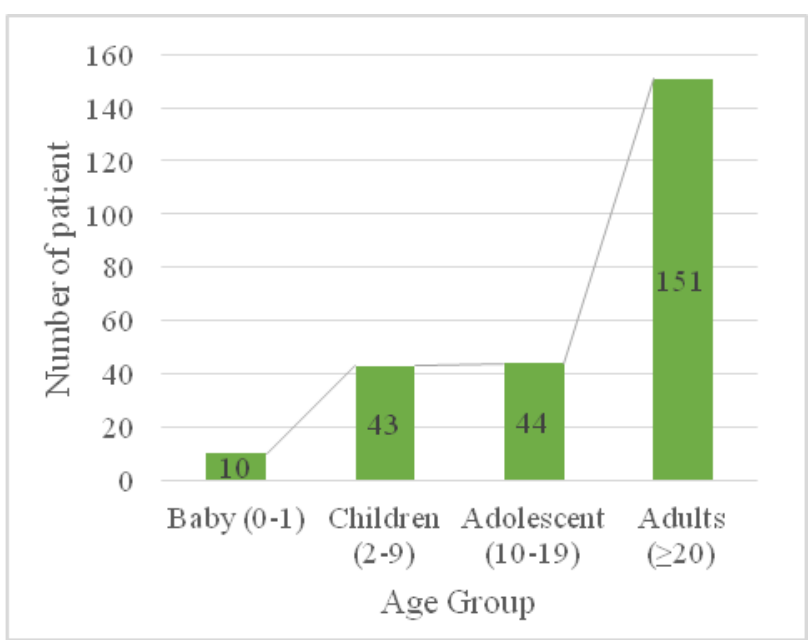

Figure 1. Graph of distribution of atopic dermatitis across age ranges

The distribution of atopic dermatitis patients according to age was ten infants $(0-1$ years), 43 children (2-9 years) (17.4\%), 44 (1019 years) adolescents ( $17.7 \%)$, and adults $(\geq 20$ years) was 151 patients $(60.9 \%)$. The age group suffering from the most dermatitis was adults ( $\geq 20$ years) with a proportion of $60.9 \%$, while the age group with the smallest proportion was infants ( $0-1$ years) at $4 \%$. 
Muhammad Ilham Arifin Muntaha, Retno Indar Widayati,

\section{DIPONEGORO MEDICAL JOURNAL}

(Jurnal Kedokteran Diponegoro)

Online : http://ejournal3.undip.ac.id/index.php/medico

E-ISSN : 2540-8844

Volume 10, Number 1, January 2021

Liza Afriliana, Aryu Candra K.

\section{b. Distribution of atopic dermatitis by gender}

Table 2. Distribution of atopic dermatitis by gender.

\begin{tabular}{ccc}
\hline Gender & $\begin{array}{c}\text { Number of } \\
\text { Patient }(\mathbf{N})\end{array}$ & Percentage \\
\hline Male & 109 & $44 \%$ \\
Female & 139 & $56 \%$ \\
Total & 248 & $100 \%$ \\
\hline
\end{tabular}

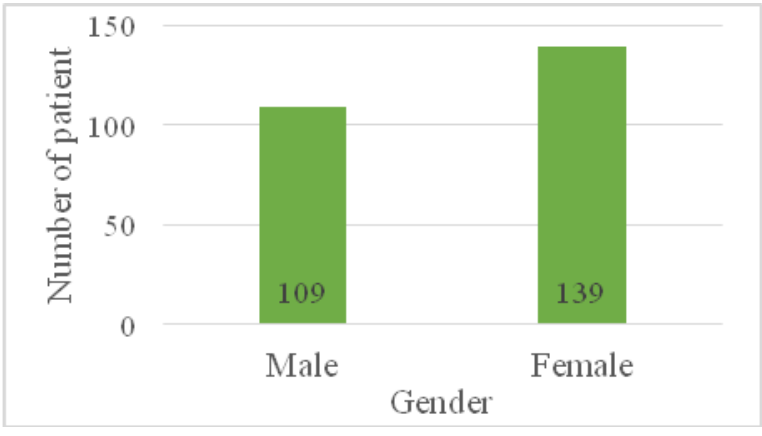

Figure 2. Graph of the distribution of atopic dermatitis by gender.

The distribution of atopic dermatitis according to gender was 109 males (44\%) and 139 females (56\%). Atopic dermatitis patients are dominated by women, with a ratio of 1: 1.27.

Distribution of atopic dermatitis by profession

Table 3. Distribution of atopic dermatitis by profession

\begin{tabular}{ccc}
\hline Profession & $\begin{array}{c}\text { Number } \\
\text { of Patient } \\
(\mathbf{N})\end{array}$ & $\begin{array}{c}\text { Percentag } \\
\mathbf{e}\end{array}$ \\
\hline Day laborer & 7 & $2,8 \%$ \\
General employees & 37 & $14,9 \%$ \\
Student & 60 & $24,2 \%$ \\
Farmers / planters & 15 & $6,0 \%$ \\
Civil servants & 11 & $4,4 \%$ \\
Entrepreneur & 22 & $8,9 \%$ \\
Unemployment & 96 & $38,7 \%$ \\
Total & 248 & $100 \%$ \\
\hline
\end{tabular}

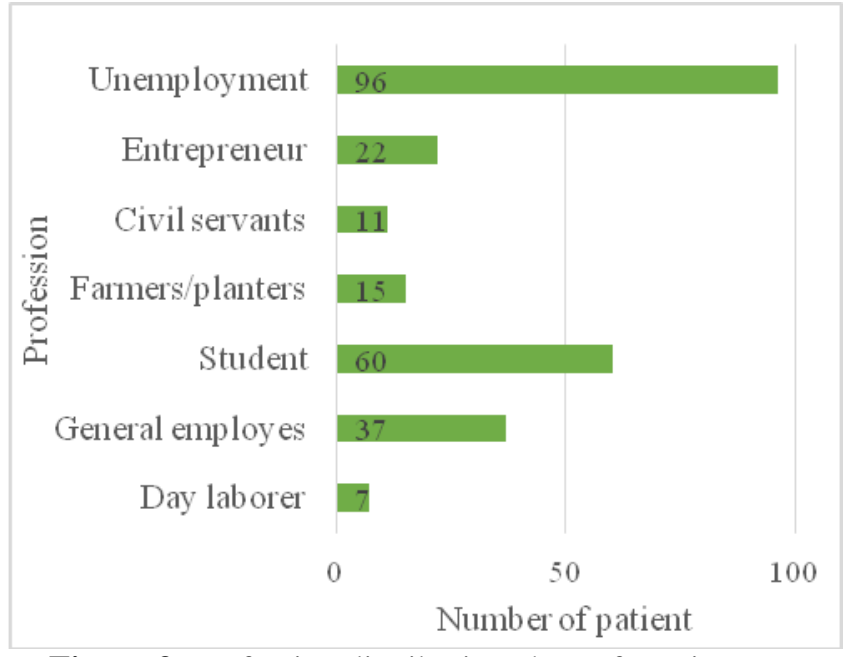

Figure 3. Profession distribution chart of atopic dermatitis

Distribution of atopic dermatitis sufferers according to the profession is day laborer was seven patient (2.8\%), general employees was 37 patient (14.9\%), students was 60 patient (24.2\%), farmers/planters was 15 patient $(6 \%)$, 11 cases of civil servants (4.4\%), 22 selfemployed patients $(8.9 \%)$ and 96 unemployed patients $(38.7 \%)$. The type of work with the most atopic dermatitis sufferers was unemployment $(38.7 \%)$, while the smallest sufferers' occupation was day laborer $(2.8 \%)$.

\section{c. Distribution of atopic dermatitis according to history of atopic disease}

Table 4. Distribution of atopic dermatitis according to history of atopic disease

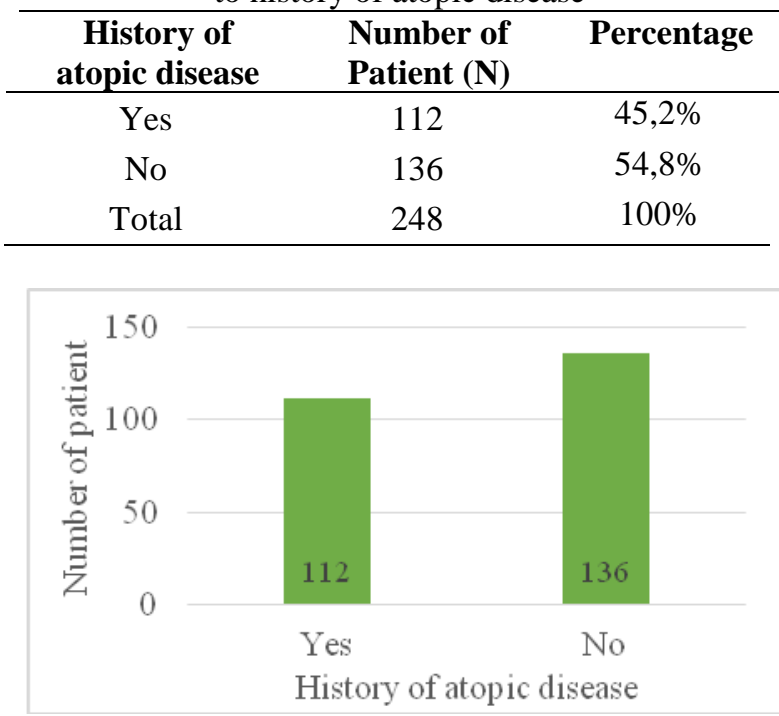

Figure 4. Graph of the distribution of atopic dermatitis on the history of atopic disease 
Muhammad Ilham Arifin Muntaha, Retno Indar Widayati,

\section{DIPONEGORO MEDICAL JOURNAL}

(Jurnal Kedokteran Diponegoro)

Online : http://ejournal3.undip.ac.id/index.php/medico

E-ISSN : 2540-8844

Volume 10, Number 1, January 2021

Liza Afriliana, Aryu Candra K

Based on the study, the distribution of atopic dermatitis with a history of atopic disease was 112 patients $(45.2 \%)$ had a previous history of atopic disease, while 136 patients $(54.8 \%)$ had no history of atopic disease.

Table 5. Distribution of atopic dermatitis by type of atopic disease

\begin{tabular}{ccc}
\hline $\begin{array}{c}\text { History of atopic } \\
\text { disease }\end{array}$ & $\begin{array}{c}\text { Number of } \\
\text { Patient (N) }\end{array}$ & Percentage \\
\hline Atopic dermatitis & 64 & $57,1 \%$ \\
Rhinoconjunctivitis & 45 & $40,2 \%$ \\
bronchial asthma & 3 & $2,7 \%$ \\
Total & 112 & $100 \%$ \\
\hline
\end{tabular}

The distribution of atopic diseases that had previously suffered was atopic dermatitis as many as 64 patients $(57.1 \%)$, rhinoconjunctivitis as many as 45 patients $(40.2 \%)$, and bronchial asthma as many as 3 patients (2.7\%).

d. Distribution of atopic dermatitis according to the location of the lesion

Table 6. Distribution of atopic dermatitis according to location of the lesion

\begin{tabular}{ccc}
\hline $\begin{array}{c}\text { Location of the } \\
\text { lesion }\end{array}$ & $\begin{array}{c}\text { Number of } \\
\text { Patient }(\mathrm{N})\end{array}$ & Percentage \\
\hline Head and neck & 40 & $16,1 \%$ \\
Body & 28 & $11,3 \%$ \\
Genitals and buttock & 32 & $12,9 \%$ \\
Upper extremity & 54 & $21,8 \%$ \\
Lower extremity & 71 & $28,6 \%$ \\
More than 1 location & 23 & $9,3 \%$ \\
Total & 248 & $100 \%$ \\
\hline
\end{tabular}

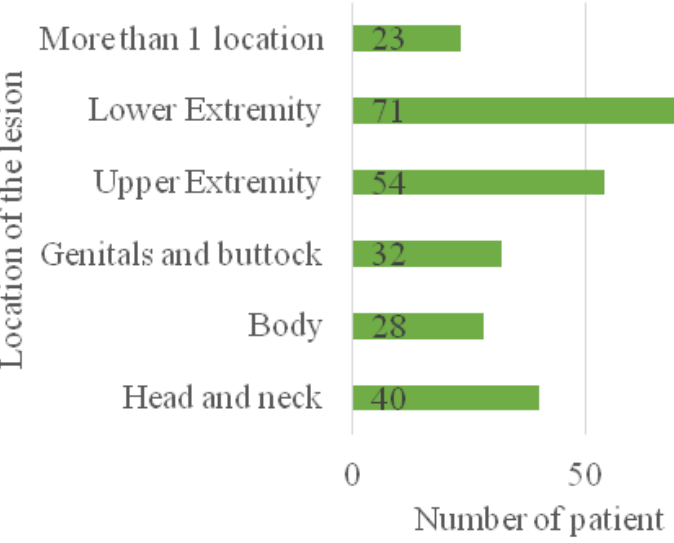

Figure 5. Graph of the distribution of atopic dermatitis to the location of the lesion
The location distribution of atopic dermatitis lesions was head and neck in 40 patients $(16.1 \%)$, body in 28 patients $(11.3 \%)$, genitals and buttocks in 32 patients (12.9\%), upper limb in 54 patients $(21,8 \%)$, lower extremities in 71 patients $(28.6 \%)$, and more than one location in 23 patients $(9.3 \%)$. The lesion's location with the most patients was the lower limb (28.6\%), while the location of the lesion with the smallest patients was the body (11.3\%).

\section{e. Distribution of atopic dermatitis according} to treatment options.

Table 7. Distribution of atopic dermatitis by type of therapy

\begin{tabular}{ccc}
\hline Type of therapy & $\begin{array}{c}\text { Number of } \\
\text { Patient (N) }\end{array}$ & Percentage \\
\hline Monotherapy & 0 & $0 \%$ \\
Polytherapy (2 types) & 31 & $12,5 \%$ \\
Polytherapy (3 types) & 103 & $41,5 \%$ \\
Polytherapy (4 types) & 82 & $33 \%$ \\
Polytherapy (5 types) & 32 & $12,9 \%$ \\
Total & 248 & $100 \%$ \\
\hline
\end{tabular}

Table 8. Distribution of atopic dermatitis according to drug of choice

\begin{tabular}{ccc}
\hline drug of choice & $\begin{array}{c}\text { Number } \\
\text { of Patient } \\
\text { (N) }\end{array}$ & Percentage \\
\hline Systemic antibiotics & 43 & $17,3 \%$ \\
Systemic & 212 & $85,5 \%$ \\
antihistamines & 41 & $16,5 \%$ \\
Systemic NSID & 117 & $47,2 \%$ \\
$\quad$ Systemic & 22 & $9,7 \%$ \\
Corticosteroids & 36 & $14,5 \%$ \\
Topical antibiotics & 107 & $43,1 \%$ \\
Keratolytics & $80,6 \%$ \\
Topical & 200 & 8 \\
Corticosteroids & &
\end{tabular}

Based on the study results, there was no mono-therapy given to patients, while the most poly-therapy was the administration of 3 types of drugs used in 103 patients $(41.5 \%)$ and the administration of 4 types of drugs to 82 patients $(33 \%)$. Systemic antibiotics were used in 43 patients $(17.3 \%)$, systemic antihistamines were used in 212 patients (85.5\%), systemic NSID 
Muhammad Ilham Arifin Muntaha, Retno Indar Widayati,

Liza Afriliana, Aryu Candra K

was used in 41 patients $(16.5 \%)$, systemic corticosteroids were used in 117 patients $(47.2 \%)$. ), topical antibiotics were used in 24 patients $(9.7 \%)$, keratolytic were used in 36 patients $(14.1 \%)$, topical corticosteroids were used in 107 patients (43.1\%), and vitamins/minerals were used in 200 patients (80, $6 \%$ ). The most commonly used types of drugs were systemic antihistamines (85.5\%) and vitamins or minerals $(80.6 \%)$, while the types of therapy that were used the least were topical antibiotics (9.7\%) and keratolytic (14.1\%).

Table 9. Name of drug used

\begin{tabular}{lc}
\hline \multicolumn{1}{c}{ Category } & Name of drug \\
\hline Systemic antibiotics & $\begin{array}{c}\text { Amoxicillin, eritromisin, } \\
\text { kotrimoksazol } \\
\text { Systemic antihistamines } \\
\text { Systemic NSID }\end{array}$ \\
$\begin{array}{l}\text { CTM, cetirizine } \\
\text { Pystemic }\end{array}$ & Paracetamol, piroxicam, \\
Corticosteroids & Prednisone, dexamethasone \\
Topical antibiotics & Kloramfenikol \\
Keratolytics & Salicylic acid \\
Topical Corticosteroids & Betamethasone, \\
& hidrokortison \\
Vitamins / Minerals & Kalsium laktat, Vit C, VitB \\
& kompleks \\
\hline
\end{tabular}

\section{DISCUSSION}

a. Distribution of atopic dermatitis by age.

The age group suffering from the most dermatitis was adults ( $\geq 20$ years) with a proportion of $60.9 \%$, while the age group with the smallest proportion was infants $(0-1$ years) at $4 \%$.

This result is different from the theory, which states that atopic dermatitis prevalence is common in children. As mentioned in the journal Immunology and Allergy Clinics of North America, atopic dermatitis affects 10-20\% of children in developed countries. Although the exact cause of why atopic dermatitis often occurs in children is not specific, there are several related factors, namely genetic factors, immune system factors, and external factors. Genetic factors include the history of parents suffering from an atopic disease. Immune system factors are associated with increased IgE due to allergens such as house dust mites and foods such as eggs and shrimp. Other external factors that cause atopic dermatitis are winter weather, using hot water for bathing, using soap, and being in dry and hot temperatures. ${ }^{12,13}$

b. Distribution of atopic dermatitis by gender

The distribution of atopic dermatitis according to gender was 109 males (44\%) and 139 females (56\%). Atopic dermatitis patients are dominated by women, with a ratio of 1: 1.27. This is caused by the influence of sex hormones. The worsening of atopic dermatitis also reinforces this theory before menstruation (luteal phase).

According to research published in the International Journal of Molecular Sciences, although the prevalence of atopic dermatitis, according to sex, tends to be higher in men than in women, after puberty, the prevalence of atopic dermatitis is more common in women. This is due to the influence of sex hormones on the immune response. In women, the hormones estrogen and progesterone increase the activity of Th2 and T cell regulators and suppress Th1 and Th17, whereas, in men, androgens suppress the activity of Th1, Th2, and Th17 and increase $\mathrm{T}$ cell regulators. One of the pathogenesis of atopic dermatitis is excessive Th2 expression. The skin's permeability and hydration in women are also better because it is strengthened by the hormone estrogen 2 (estradiol). However, this hormone has a paradoxical effect on exacerbating the skin barrier's breakdown when the hormone progesterone triggers the damage. This paradoxical effect occurs in menstruation's luteal phase, where the hormones progesterone and estrogen are excreted simultaneously. ${ }^{14,15}$

\section{c. Distribution of atopic dermatitis by profession}

The type of work with the most atopic dermatitis sufferers was unemployment (38.7\%), while the smallest sufferers' occupation was day laborer (2.8\%). The non-working group consisted of preschool children, homemakers, and retirees. Atopic dermatitis affects many children and women after puberty. This causes the prevalence of atopic dermatitis in the unemployed group to be higher than in other occupations. $^{12,14}$

\section{d. Distribution of atopic dermatitis according to history of atopic disease}

Atopic dermatitis patients' distribution to atopic history was 112 patients $(45.2 \%)$ had a 
previous history of atopic disease, while 136 patients (54.8\%) had no history of atopic disease. Furthermore, the distribution of atopic diseases that had previously suffered was atopic dermatitis was 64 patients $(57.1 \%)$, rhinoconjunctivitis was 45 patients $(40.2 \%)$, and bronchial asthma was three patients (2.7\%). These results indicate that some patients with atopic dermatitis have a history of atopic disease. A history of atopic dermatitis in $25.8 \%$ of patients also indicated that atopic dermatitis was chronic in $25.8 \%$ of patients. This is under what is written in the book Atopic Dermatitis by Jonathan Ring, which states that atopic dermatitis is persistent in $32.2 \%$ of sufferers and the ISRN Allergy journal that atopic dermatitis can cause recurrence in $25 \%$ of patient. ${ }^{10,16}$

A history of rhinoconjunctivitis and asthma is also believed to be associated with atopic dermatitis. One of the causes of rhinoconjunctivitis, asthma, and atopic dermatitis is an adaptive immune system disorder that results in increased and overexpression of $\operatorname{IgE}$ to antigens. Increased $\operatorname{IgE}$ occurs in $80 \%$ of patients with atopic dermatitis. In genetic etiology, the emergence of rhinoconjunctivitis in patients with atopic dermatitis occurs due to defects in the 16p11.212.1 gene, while the appearance of asthma in atopic dermatitis occurs due to damage to gen $11 \mathrm{q} 13$, gene 16p11.2-12.1, gene 17q11-q12, gene $17 \mathrm{q} 21$, etc. ${ }^{10,17}$

\section{e. Distribution of atopic dermatitis according to the location of the lesion}

The lesion's location with the most patients was the lower limb (28.6\%), while the location of the lesion with the smallest patients was the body (11.3\%).

The location of atopic dermatitis varies with each age. In the data, most age groups are adolescents and adults (aged over ten years) and 190 patients $(76.6 \%)$. In this group, the lesions' location usually affects the upper extremities, head, and neck. The data obtained is not following the theory. In infancy (age less than two years), atopic dermatitis often affects the face, scalp, extensors of the arms, and legs, while in childhood (ages 2-10 years), it often affects flexion of the elbows, knees, and ankles. ${ }^{16,18,19}$

\section{f. Distribution of atopic dermatitis according to treatment options.}

There was no monotherapy given to patients, while the most polytherapy was the administration of 3 types of drugs used in 103 patients $(41.5 \%)$ and the administration of 4 types of drugs to 82 patients (33\%). Systemic antibiotics were used in 43 patients (17.3\%), systemic antihistamines were used in 212 patients $(85.5 \%)$, systemic NSID was used in 41 patients $(16.5 \%)$, systemic corticosteroids were used in 117 patients $(47.2 \%)$. ), topical antibiotics were used in 24 patients $(9.7 \%)$, keratolytic were used in 36 patients $(14.1 \%)$, topical corticosteroids were used in 107 patients $(43.1 \%)$, and vitamins/minerals were used in 200 patients $(80,6 \%)$. The most commonly used types of drugs were systemic antihistamines $(85.5 \%)$ and vitamins/minerals (80.6\%), while the types of therapy that were used the least were topical antibiotics (9.7\%) and keratolytic $(14.1 \%)$.

In the atopic dermatitis guidelines for Asia published in the journal Asia Pacific Allergy, atopic dermatitis primary therapy is to avoid trigger factors such as hot and humid environments, cutting nails, wearing light clothing and avoiding synthetic material that dissipate heat and sweat poorly, and caring for pets. Then for topical therapy in the first line, moisturizers and cleansers can be given. The moisturizer that is given is a humectant, occlusive, and emollient. While the cleaners used are soap and sodium hypochlorite. For the next therapy, only given topical corticosteroid if the moisturizer and cleanser therapy failed. For systemic therapy, systemic corticosteroids and antihistamines can be given. The results showed that the use of polytherapy most often consisted of antihistamines, corticosteroids, and vitamins/minerals, whereas the provision of education and moisturizers were absent. This is because doctors do not write down their education in medical records, and Puskesmas Masaran 1 does not provide a moisturizer for the treatment of atopic dermatitis patients. ${ }^{20}$

\section{CONCLUSIONS AND SUGGESTIONS}

\section{a. Conclusions}

The characteristics of atopic dermatitis at Puskesmas Masaran 1 are that the most age 
group is adults, the most sex is women, the most type of work is unemployment, the most history of atopic disease is atopic dermatitis, and the most widely used treatment options are corticosteroids, antihistamines, and vitamins/minerals.

\section{b. Suggestions}

It is necessary to explain to people with atopic dermatitis that the disease is chronic and residing, usually has a history of atopic in themselves or their family, often appears in infancy and childhood, and can turn into rhinoconjunctivitis at a higher age. Further research is needed regarding atopic dermatitis's relationship to other risk factors, such as lifestyle, location of residence, comorbid diseases, etc.

\section{ACKNOWLEDGEMENT}

The researcher would like to thank dr. Retno Indar Widayati, M. Si, Sp. KK (K), FINSDV, and also dr. Liza Afriliana, Sp. KK who has guided and provided suggestions in making scientific papers. The researcher also thanked dr. Aryu Candra K. M.Kes.Epid as chairperson of the examiner and other parties who have helped so that this research can carry out well.

\section{REFERENCES}

1. Sihaloho K, Indramaya M. Penelitian Retrospektif: Dermatitis Atopik pada Anak (Retrospective Study: Atopic Dermatitis in Childhood). Portal Garuda. 2015;27(3):177-9.

2. Evina B. Clinical manifestations and diagnostic criteria of atopic dermatitis. J Major. 2015;4(4):23-30.

3. Herwanto N, Hutomo M. Studi retrospektif: penatalaksanaan dermatitis atopik (Retrospective study: management of atopic dermatitis ). Berk Ilmu Kesehat Kulit dan Kelamin. 2016;28(1):8-17.

4. Pandaleke TA, Pandaleke HEJ. Etiopatogenesis Dermatitis Atopi. J Biomedik. 2014;6(2):76-83.

5. Bakhtiar. Faktor Risiko , Diagnosis , dan Tatalaksana Dermatitis Atopik pada Bayi dan Anak. Maranatha J Med Heal. 2010;9(2):188-98.

6. Murlistyarini S, Prawitasari S, Setyowatie
L. Dermatitis Atopi. In: Intisari Ilmu Kesehatan Kulit dan Kelamin. 1st ed. Malang: UB Press; 2018. p. 241-54.

7. Utami DN. Disfungsi Sawar Epidermis dan Strategi Penanganan Dermatitis Atopik. CKD-215. 2014;41(4):254-9.

8. Citrashanty I, Rosita C, Prakoeswa S. Kerusakan Sawar Kulit pada Dermatitis Atopik (Skin Barrier Dysfunction in Atopic Dermatitis). Berk Ilmu Kesehat Kulit dan Kelamin. 2012;2(318):49-54.

9. Paramita OD, Harsono N, Setiawan H. Hubungan Asma, Rinitis Alergik, Dermatitis Atopik dengan IgE Spesifik Anak Usia 6 - 7 Tahun. Sari Pediatr. 2016;14(6):391-7.

10. Ring J, Hanifin J. Clinical Symptoms of Atopic Eczema. Internatio. Atopic Dermatitis. Switzerland: Springer International Publishing; 2016. 27-67 p.

11. Ashariani S. Tatalaksana Non-Farmakologi pada Dermatitis Atopik NonPharmacologic Therapies in Atopic Dermatitis. J Agromed Unila. 2015;2(4):516-22.

12. Yamamoto-Hanada $\mathrm{K}$, Yang L, Ishitsuka $\mathrm{K}$, Ayabe T, Mezawa H, Konishi M, et al. Allergic profiles of mothers and fathers in the Japan Environment and Children's Study (JECS): A nationwide birth cohort study. World Allergy Organ J. 2017;10(1):1-7.

13. Lyons JJ, Milner JD, Stone KD. Atopic Dermatitis in Children: Clinical Features, Pathophysiology, and Treatment. Immunol Allergy Clin North Am. 2015 Feb 1;35(1):161-83.

14. Kanda N, Hoashi T, Saeki H. The roles of sex hormones in the course of atopic dermatitis. Int J Mol Sci [Internet]. 2019 Oct 1;20(19):4660. Available from: /pmc/articles/PMC6802354/?report=abstrac $\mathrm{t}$

15. Dor-Wojnarowska A, Liebhart J, Miecielica J, Rabski M, Fal A, Samoliński B, et al. The Impact of Sex and Age on the Prevalence of Clinically Relevant Sensitization and Asymptomatic Sensitization in the General Population. Arch Immunol Ther Exp (Warsz) [Internet]. 2017 Jun 1;65(3):253-61. 
Available from: /pmc/articles/PMC5434121/?report=abstrac $\mathrm{t}$

16. Thomsen SF. Atopic Dermatitis: Natural History, Diagnosis, and Treatment. ISRN Allergy [Internet]. 2014;2014:1-7. Available from: /pmc/articles/PMC4004110/?report=abstrac $\mathrm{t}$

17. Kasperkiewicz M, Schmidt E, Ludwig RJ, Zillikens D. Targeting IgE Antibodies by Immunoadsorption in Atopic Dermatitis. Front Immunol [Internet]. 2018 Feb 19;9(254):1-5. Available from: /pmc/articles/PMC5827554/?report=abstrac $\mathrm{t}$

18. Kolb L, Ferrer-Bruker SJ. Atopic Dermatitis [Internet]. StatPearls. StatPearls Publishing; 2020 [cited 2020 Oct 14]. Available from: http://www.ncbi.nlm.nih.gov/pubmed/2884 6349

19. Kanwar AJ. Adult-onset atopic dermatitis. Indian J Dermatol [Internet]. 2016 Nov 1;61(6):662-3. Available from: /pmc/articles/PMC5122283/?report=abstrac $\mathrm{t}$

20. Chow S, Seow C, Dizon M, Godse K, Foong H, Chan V, et al. A clinician's reference guide for the management of atopic dermatitis in Asians. Asia Pac Allergy. 2018 Oct 29;8(4):e41. 